\title{
Alkaline Extraction for Lead Determination in Different Types of Commercial Paints
}

\author{
David Romero-Estévez *D, Gabriela S. Yánez-Jácome, Karina Simbaña-Farinango, \\ Pamela Y Vélez-Terreros and Hugo Navarrete *
}

Centro de Estudios Aplicados en Química, Pontificia Universidad Católica del Ecuador, CESAQ-PUCE, Ecuador, Av. 12 de Octubre 1076 y Roca, Quito, Pichincha 17012184, Ecuador; gsyanez@puce.edu.ec (G.S.Y.-J.); kjsimbanaf@puce.edu.ec (K.S.-F.); pameyvt@gmail.com (P.Y.V.-T.)

* Correspondence: dfromero@puce.edu.ec (D.R.-E.); hnavarrete@puce.edu.ec (H.N.); Tel.: +593-2-2991712 (D.R.-E.)

Received: 11 July 2019; Accepted: 25 September 2019; Published: 1 November 2019

\begin{abstract}
In 2017, the World Health Organization and the United Nations Environment Programme formed the Global Alliance to Eliminate Lead Paint. All alliance member countries have pledged to develop control regulations that include lead threshold limits. To improve regulations and demonstrate compliance of paint industry products, it is necessary to have adequate, locally applicable methodologies. In this sense, the main objective of this research was to validate the methodology of alkaline extraction for the quantification of lead in ten different types of Ecuadorian commercial paints using flame atomic absorption spectrophotometry. Two hundred and fifty samples from different paint industry products were analyzed, and the results were used to evaluate the method's performance and robustness. It was determined that the method could be applied for lead concentrations above $100 \mathrm{mg} \cdot \mathrm{kg}^{-1}$, and results showed relative standard deviation values lower than $14.8 \%$ and fortification recoveries between 80.3 and $119.4 \%$, fulfilling the acceptance criteria established in the Environmental Protection Agency's lead-based Paint Laboratory Operations Guidelines.
\end{abstract}

Keywords: alkaline extraction; flame atomic absorption; regulation; solvent-base; water-base

\section{Introduction}

Lead $(\mathrm{Pb})$ is a toxic metal that can accumulate in living tissue and affect the neurological, cardiovascular, and renal systems [1,2]. Humans' intake of $\mathrm{Pb}$ alters the normal physiology of their biological systems. Although it has not yet been demonstrated that dermal exposure is an important entry route for humans [3], in the case of children, hand-to-mouth behaviors and the rapid absorption of ingested $\mathrm{Pb}$ increase its health risks.

The main sources of $\mathrm{Pb}$ exposure are contaminated food and water intake. Additional means of exposure include contact with toys, paints, coatings, and metallic materials such as jewelry that contain this metal [4-6]. According to statistical studies conducted by the World Health Organization (WHO), $\mathrm{Pb}$ exposure accounted for approximately half a million deaths in 2016 [7], 82\% of which occurred in developing countries [8]. Architectural paints and household items are an important exposure source because of their proximity to people; these products also continue to be sold despite their high $\mathrm{Pb}$ content [9]. In 2017, the United Nations Environment Programme (UNEP) reported that only one-third of 193 countries have regulations related to the use of $\mathrm{Pb}$ in paints [8]. In response to the frequent incidence of high $\mathrm{Pb}$ concentrations in paints, especially in decorative glazes, and the possible health conditions that they could cause, the WHO, together with the UNEP, formed the Global Alliance to Eliminate Lead Paint (GAELP) $[9,10]$. This alliance has as its main objective the elimination of $\mathrm{Pb}$ in 
paints by 2020 [8]. Every alliance member country has pledged to develop control regulations that include $\mathrm{Pb}$ threshold limits.

To perform paint quality control and establish $\mathrm{Pb}$ threshold values, there are several analytical methods described in the literature. These methods include the following: dry ashing [11] and wet acid digestions either on a heating plate or in a microwave [12] to prepare samples; atomic absorption spectrophotometry [5,11,13-15]; inductively coupled plasma emission spectroscopy quantification [16-20]; the Delves micro-sampling technique [21]; and non-destructive techniques such as X-ray fluorescence [4] for quantification. In Ecuador, the most frequently used methods are the dry ashing technique [11,22] and wet acid digestion [22].

In its Pb-Based Paint Laboratory Operations Guidelines: Analysis of Pb in Paint, Dust, and Soil [12], the Environmental Protection Agency (EPA) does not recommend using the dry ashing technique because it is difficult to control. In addition, heating homogeneity cannot be guaranteed, and avoiding splatter/cross-contamination of samples is challenging. Wet acid digestion techniques are preferable to dry ashing, but when only nitric acid is used, an incomplete digestion process can occur. A different wet acid digestion technique that uses a mixture of nitric acid and hydrogen peroxide may be suitable for the digestion of most samples. Nevertheless, these methods have not been validated for certain matrices, including solvent-based paints, epoxy, alkyd enamels, and synthetic enamels, among others. Methods that use perchloric acid in combination with nitric acid have shown acceptable results, but they are not recommended because of the myriad of safety precautions for perchloric acid use. On the other hand, most of the methods described in the literature have been applied to dry paint products (paint chips or powder) [5,11,13-15]; therefore, the acceptable performance of these techniques for liquid products or solvent-based paints is still unknown.

An alternative less commonly used method known as Method A is described in ISO 6503:1984 [23]. This method consists of wet oxidation of the sample using a mixture of sulfuric acid and hydrogen peroxide, followed by an alkaline extraction of $\mathrm{Pb}$ in the residue with ethylenediaminetetra-acetic acid (EDTA) and ammonia solution. This ISO alternative method is meant to coat materials with $\mathrm{Pb}$ content in the range of about $0.01 \%$ mass fraction $(w / w) 2 \%(w / w)$. The principle behind this extraction technique involves forming a Pb-chelating ligand using the EDTA as a chelating agent and ammonium cation ligands. This technique is commonly used for metal extraction from soil matrices [24-27].

In 2015, the Ecuadorian Standardization Service (abbreviated INEN in Spanish) formed the National Technical Committee for Paints (abbreviated CTN in Spanish). This committee discussed the inclusion of $\mathrm{Pb}$ threshold values in the standards for all paint products according to their intended use. This process is still ongoing, and the threshold values are expected to be included in the new versions of all paint standards and regulations. Presently, a threshold value of $100 \mathrm{mg} \cdot \mathrm{kg}^{-1} \mathrm{of} \mathrm{Pb}$ has been established for architectural and domestic use paints [28,29] and a $600 \mathrm{mg} \cdot \mathrm{kg}^{-1}$ threshold value for traffic and vehicular use paints [30]. Regarding standards for other paint products, like traffic paints and synthetic alkyd enamels for domestic use [31,32], the only requirement is that "the raw materials must be free of $\mathrm{Pb}^{\prime}$. Furthermore, for some paints and coatings, including anti-corrosive primers, anti-corrosive coatings, nitrocellulose and polyester putties, lacquers, and wood sealants [33-44], there are no established $\mathrm{Pb}$ regulations.

Because of the drafting of these new standards, there is now an imperative to develop local methodologies to ensure that industries are producing, importing, and marketing $\mathrm{Pb}$-free paints. In response to this need, the main objective of this study was to validate the analytical ISO 6503:1984 alkaline extraction method [23] to quantify $\mathrm{Pb}$ in ten different types of paints. To accomplish this, different local producers and marketers provided paint samples; thus, this study constitutes the first effort to determine $\mathrm{Pb}$ content in local products in Ecuador.

\section{Materials and Methods}

The initial tests were carried out using trace metals-i.e., paint chips, a certified reference material (Sigma-Aldrich Inc; CRM013-50G)—and different methods including dry ashing [11,23], wet acid 
digestion [12], and alkaline extraction [23] techniques. The final analysis method selected for the samples was alkaline extraction, a wet digestion procedure known as Method A in ISO 6503:1986 [23]. This method was chosen because it complies with the quality assurance parameters concerning precision and accuracy established in the EPA's Pb-Based Paint Laboratory Operations Guidelines [12].

Between April 2015 and January 2019, 10 main local manufacturers and marketers provided 250 paint samples corresponding to water-based paint, solvent-based paint, epoxy, alkyd enamels, synthetic enamels, lacquers, putties, pure pigments, preformed thermoplastics, and resins. All the samples were analyzed using the alkaline extraction and flame atomic absorption spectrophotometry (FAAS) methodology [23].

The paint decomposition process was done according to the procedure shown in Figure 1 using a heating plate (OVAN, model MMH90E), sulfuric acid (Pharmco-Aaper, analytical grade CAS\# 7664-93-9), and 30\% hydrogen peroxide (Fisher Chemical, analytical grade CAS\# 7722-84-1).
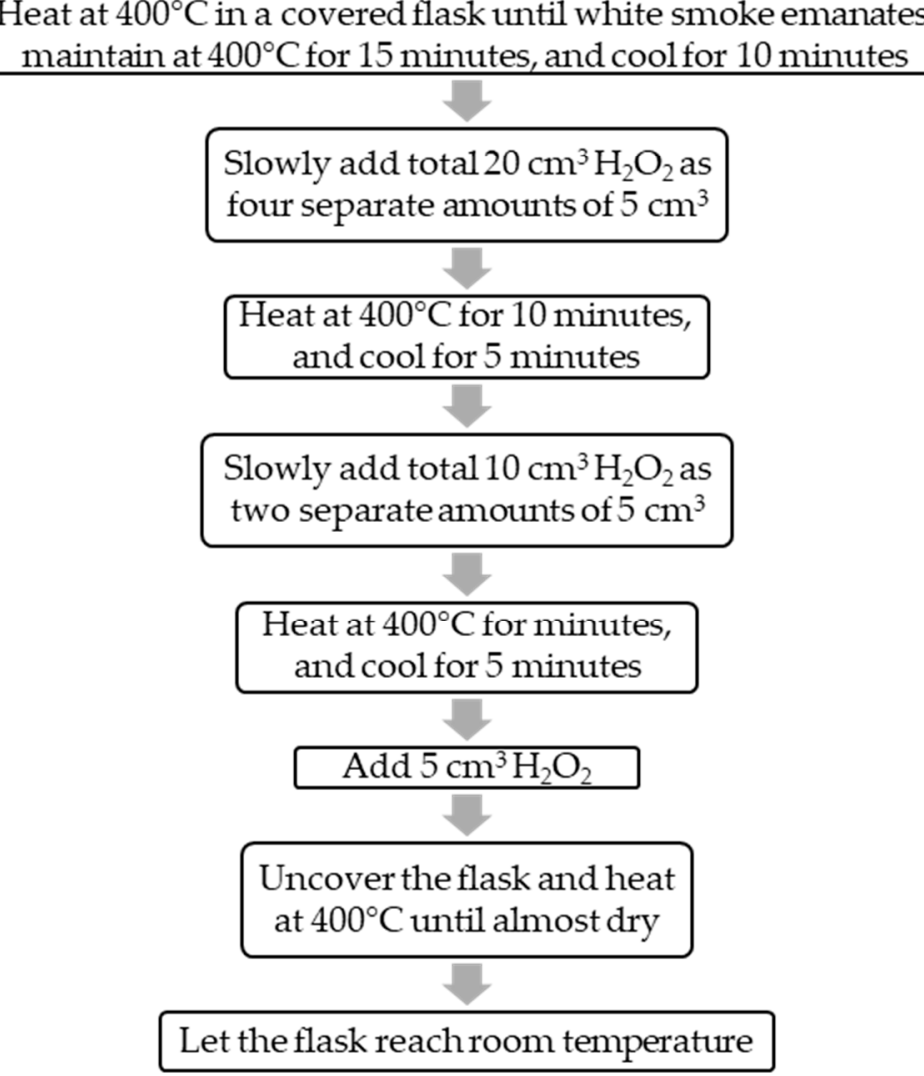

Figure 1. Paint decomposition process. Erlenmeyer flasks were used instead of glasses [23] to avoid splatter.

The $\mathrm{Pb}$ extraction process from paints was done according to the procedure shown in Figure 2 using disodium salt of EDTA (Lobachemie, analytical grade, CAS\# 6381-92-6), an ammonium hydroxide solution (Merck Trademark 25\%, analytical grade, CAS\# 1336-21-6), and medium-quality reagent water. 


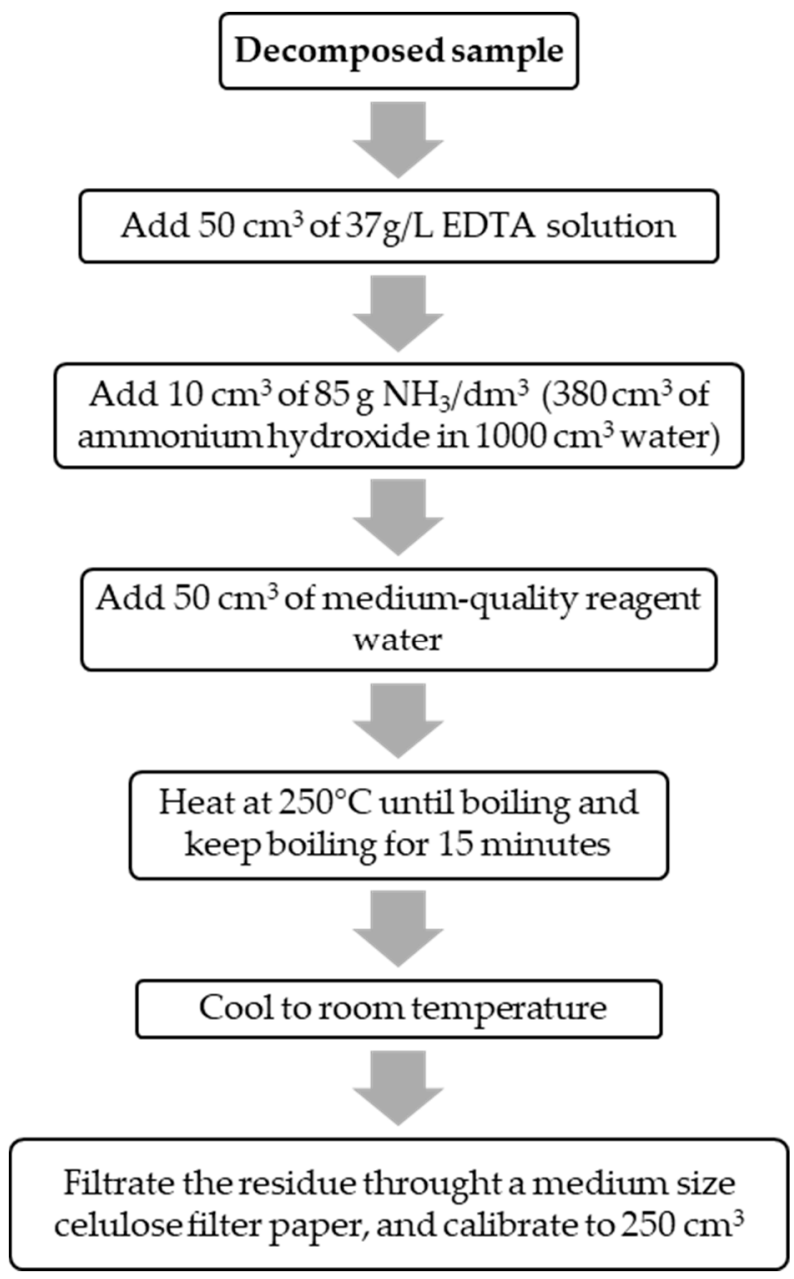

Figure 2. Lead alkaline extraction from the paints.

The $\mathrm{Pb}$ quantification was conducted using FAAS (Perkin Elmer, AAnalyst 400) with a hollow $\mathrm{Pb}$ cathode lamp (Perkin Elmer). Calibration curves were performed with $0.2,1.2,3.0$, and $5.0 \mathrm{mg} \cdot \mathrm{dm}^{-3}$ standard dilutions prepared from a $1000 \mathrm{mg} \cdot \mathrm{dm}^{-3}$ certified reference material (Inorganic Ventures, catalog CGPB1). Linearity was evaluated with regression analysis, where a lack-of-fit test was used at a $95 \%$ confidence level for the daily group of results of all the external standards used (i.e., samples fortifications, calibration curve control standards).

The limits of detection (LOD) for Pb were based on the variability of the blank, calculated by multiplying the standard deviation of the mean blank concentration values by three [12]. The limits of quantification (LOQ) values were determined experimentally by analyzing fortification samples in low concentrations that fall within the EPA precision and accuracy acceptance criteria [12].

Quality assurance was carried out following the specifications described in Section 3.4.1 of the EPA guidelines [12]. Precision was determined using triplicates of each sample analysis and expressed as the relative standard deviation (RSD). Accuracy was calculated using fortification recoveries by adding $150 \mathrm{mg} \cdot \mathrm{kg}^{-1}$ of $\mathrm{Pb}$ to each sample, since specific product reference materials for each type of paint do not exist. Fortifications were simultaneously analyzed with the samples, and expressed as recovery rates. In addition, initial calibration verification, an initial calibration blank, continuing calibration verification, and method blank verification were done for quality assurance.

The acceptance criteria used was in accordance with Section 3.4.4 of the EPA guidelines [12], as follows:

- Initial calibration verification: within $\pm 10 \%$ of the known value of the standard control. 
- Initial calibration blank: an absolute value of no more than $20 \%$ of the LOQ value.

- Continuing calibration verification: within $\pm 10 \%$ of the known value of the standard control.

- Continuing calibration blank: an absolute value of no more than $20 \%$ of the LOQ value.

- Matrix spike (fortifications): within $\pm 25 \%$ of the known value.

- Triplicate sample: within $\pm 25 \%$ of the RSD.

- Method blank: an absolute value of no more than $20 \%$ of the LOQ value.

\section{Results}

\subsection{Method Validation}

The initial tests were carried out using dry ashing and wet acid digestion techniques [11,15,22], without obtaining satisfactory precision and accuracy results. In several cases, RSD results were higher than $25 \%$ and fortification recoveries lower than $75 \%$. For this reason, the alkaline extraction process was selected as an adequate preparation technique, since its performance was in accordance with the acceptance criteria described by the EPA [12] in Section 3.4.4: RSD values lower than $25 \%$ and fortifications recoveries within $100 \pm 25 \%$.

During the validation process, for each day of analysis, a $0.2 \mathrm{mg} \cdot \mathrm{dm}^{-3}$ standard was analyzed in terms of initial and continuing calibration verification; recovery results obtained were within $100 \pm 10 \%$ (internal laboratory acceptance criteria). All the calibration blanks (initial, continuing, and method) were lower than $0.009 \mathrm{mg} \cdot \mathrm{dm}^{-3}$ ( $4.5 \%$ of the LOQ value).

Each sample was analyzed in triplicate to verify precision; in addition, a fortification was used for each sample to ensure the accuracy of the extraction method performed.

As seen in the results shown in Table 1, the alkaline extraction methodology with FAAS was adequate to quantify $\mathrm{Pb}$ concentrations between 100 and $21,044.5 \mathrm{mg} \cdot \mathrm{kg}^{-1}$. Instrumental LOD was calculated using the RSD for the blanks (multiplied by three); the LOD value was $0.5 \mathrm{mg} \cdot \mathrm{kg}^{-1}$. Although the LOQ was obtained using fortifications in low concentrations; the LOQ was $100 \mathrm{mg} \cdot \mathrm{kg}^{-1}$, and this value was not only within the acceptance criteria of the EPA Pb-Based Paint Laboratory Operations Guidelines [12], but it was also adequate to evaluate the $\mathrm{Pb}$ content using the Ecuadorian regulations. The maximum RSD obtained for all types of paints was $14.8 \%$; this value was lower than the EPA acceptance criteria (25\%). Considering all the types of paints analyzed, the fortification recoveries were between 80.3 and $119.4 \%$, which were within the acceptance criteria recoveries corresponding to between 75 and $125 \%$. 
Table 1. Lead content range $\left(\mathrm{mg}_{\mathrm{kg}}{ }^{-1}\right)$, rates of standard deviation (RSD, \%), and fortification recovery rates (\%).

\begin{tabular}{|c|c|c|c|c|c|c|c|c|c|c|}
\hline \multirow{2}{*}{ Paint Product } & \multirow{2}{*}{ Number of Samples } & \multicolumn{3}{|l|}{$\mathrm{Pb}$ Concentrations } & \multicolumn{3}{|l|}{ RSD } & \multicolumn{3}{|c|}{ Fortification Recovery Rates } \\
\hline & & Minimum Value & Maximum Value & Mean Value & Minimum Value & Maximum Value & Mean Value & Minimum Value & Maximum Value & Mean Value \\
\hline water-based $^{1}$ & 135 & $<\mathrm{LOD}$ & $12,715.3$ & 738.4 & $0.0 \%$ & $14.8 \%$ & $4.7 \%$ & $80.8 \%$ & $119.2 \%$ & $101.1 \%$ \\
\hline solvent-based & 38 & $<\mathrm{LOD}$ & $10,502.9$ & 1316.7 & $0.0 \%$ & $13.7 \%$ & $4.7 \%$ & $80.4 \%$ & $119.4 \%$ & $101.4 \%$ \\
\hline epoxy & 5 & 16.2 & 3081.7 & 1167.8 & $0.7 \%$ & $11.6 \%$ & $4.7 \%$ & $83.9 \%$ & $114.1 \%$ & $100.2 \%$ \\
\hline alkyd enamels 2,3 & 4 & 172.8 & 727.7 & 447.0 & $0.9 \%$ & $8.1 \%$ & $5.0 \%$ & $82.2 \%$ & $108.7 \%$ & $97.0 \%$ \\
\hline synthetic enamels & 40 & $<$ LOD & $21,044.5$ & 5578.5 & $0.0 \%$ & $13.4 \%$ & $2.8 \%$ & $80.3 \%$ & $119.3 \%$ & $101.7 \%$ \\
\hline lacquers ${ }^{1}$ & 2 & 483.4 & 826.5 & 654.9 & $4.7 \%$ & $6.0 \%$ & $5.3 \%$ & $94.0 \%$ & $109.0 \%$ & $101.5 \%$ \\
\hline putties & 5 & $<$ LOD & 98.5 & 37.1 & $0.0 \%$ & $12.4 \%$ & $5.6 \%$ & $94.7 \%$ & $109.3 \%$ & $103.4 \%$ \\
\hline pure pigments & 9 & $<$ LOD & 145.1 & 33.1 & $0.0 \%$ & $11.4 \%$ & $3.7 \%$ & $92.0 \%$ & $118.4 \%$ & $101.4 \%$ \\
\hline preformed thermoplastics ${ }^{2}$ & 8 & $<$ LOD & 77.0 & 20.9 & $0.0 \%$ & $2.7 \%$ & $1.6 \%$ & $86.6 \%$ & $107.1 \%$ & $97.9 \%$ \\
\hline resins & 4 & 4.6 & 189.9 & 124.4 & $0.8 \%$ & $10.8 \%$ & $7.4 \%$ & $102.0 \%$ & $115.9 \%$ & $107.4 \%$ \\
\hline TOTAL & 250 & 4.6 & $21,044.5$ & 1011.9 & $0.0 \%$ & $14.8 \%$ & $4.6 \%$ & $80.3 \%$ & $119.4 \%$ & $101.3 \%$ \\
\hline
\end{tabular}

LOD: Limits of detection. Ecuadorian regulations' requirement specifications: ${ }^{1}$ Architectural and domestic use paints: threshold value $100 \mathrm{mg} \cdot \mathrm{kg}^{-1}$ [28,29]. ${ }^{2}$ Raw materials must be $\mathrm{Pb}$-free [30]. ${ }^{3}$ Traffic and automotive industry paints: threshold value $600 \mathrm{mg} \cdot \mathrm{kg}^{-1}[31,32]$. 


\subsection{Pb Content of Paint Samples}

The sample results varied (Table 1); some samples reached values up to $21,044.5 \mathrm{mg} \cdot \mathrm{kg}^{-1}$ (average $\left.5578.5 \mathrm{mg} \cdot \mathrm{kg}^{-1}\right)$. On the other hand, there were samples with results lower than the LOD. The samples below the LOD were water-based paints $(4.4 \%)$, solvent-based paints $(5.3 \%)$, synthetic enamels $(2.5 \%)$, mastics $(20.0 \%)$, pigments (22.2\%), and thermoplastic preforms (37.5\%).

\section{Discussion}

The dry ashing techniques [11,22] showed fortification recoveries lower than $75 \%$ (data not shown). There were two presumed reasons for this low performance: first, dry ashing techniques are difficult to control, and there is a possibility of uneven heating or splatter/cross-contamination. Second, the exclusive use of nitric acid for the ash digestion could result in an incomplete digestion process [12].

The wet acid digestion technique [23] was only applied on pigmented coatings to evaluate the calcination method; nevertheless, the American Society for Testing and Materials ASTM [11] mention that "there is no reason to believe that varnishes and lacquers could not be analyzed successfully, provided that appropriate precautions are taken".

When alternative hot plate digestion techniques [15] were used, not all cases resulted in acceptable fortification recoveries. The EPA mentions that wet digestion techniques that use a mixture of nitric acid and hydrogen peroxide can be used for $\mathrm{Pb}$ extraction from most types of paint products. However, a complete method validation is necessary for each type of paint product to ensure its performance [12]. The use of sulfuric acid instead of nitric acid could help guarantee a complete digestion process for most paint components, also allow complete oxidation of organic matter, breaking the organic-metal ligands.

In the case of microwave digestion techniques, the Truman State University experimental procedure [15] has only been tested with paint chips, which does not guarantee its acceptable performance for liquid paint products. In addition, the danger of applying high temperatures and pressures to solvent-based paints, lacquers, and other products that contain explosive or flammable compounds must be considered.

The validation results confirmed the adequate performance of the alkaline extraction methodology and the $\mathrm{Pb}$ quantification using FAAS. Regarding the quality assurance of the results, the recovery results measured against the calibration curve control standards (initial and continuing) were below $10 \%$, and all the calibration blanks (initial, continuing, and method) were lower than $20 \%$ of the LOQ value, which was within the acceptable range established in Section 3.4.4 of the EPA's guidelines [12]. The triplicate RSD values were below $25 \%$, and the recovery rates of the fortifications were between 75 and $125 \%$. The fulfillment of all the aforementioned criteria shows the adequate performance of the analytical method, and its applicability for the 10 types of paint products included in the study. The robustness of the methodology was evaluated by comparing the results obtained for every type of paint product to the EPA acceptance criteria [12].

The sample results demonstrated not only the varied $\mathrm{Pb}$ content among and within the different types of paints but also that, in some cases, the $\mathrm{Pb}$ concentrations were above the threshold values stipulated in the Ecuadorian regulations. In the case of synthetic enamels (average $5578.5 \mathrm{mg} \cdot \mathrm{kg}^{-1}$ ), solvent-based paints (average $1316.7 \mathrm{mg} \cdot \mathrm{kg}^{-1}$ ), and epoxy paints (average $167.8 \mathrm{mg} \cdot \mathrm{kg}^{-1}$ ), the $\mathrm{Pb}$ content exceeded the threshold values by 20 and 50 times for paints for traffic and architectural use, respectively.

In a related study conducted by Clark et al. [9] in several different countries, products with $\mathrm{Pb}$ contents of 25,000 mg. $\mathrm{kg}^{-1}$ (Armenia), 15,700 mg. kg ${ }^{-1}$ (Kazakhstan), 16,600 mg $\cdot \mathrm{kg}^{-1}$ (India), and $5600 \mathrm{mg} \cdot \mathrm{kg}^{-1}$ (Brazil) were identified. In Brazil, implemented regulations had led to the reduction of the $\mathrm{Pb}$ content as the products initially contained an average of $36,000 \mathrm{mg} \cdot \mathrm{kg}^{-1} \mathrm{of} \mathrm{Pb}$. All these results show similar values to those of the present study (the highest $\mathrm{Pb}$ concentration was $21,044.5 \mathrm{mg} \cdot \mathrm{kg}^{-1}$ ). In another study conducted by Gottesfeld, Pokhrel, and Pokhrel, [5] on decorative paints in Nepal, 
the $\mathrm{Pb}$ concentration values were between 3448.0 and $54,755.0 \mathrm{mg} \cdot \mathrm{kg}^{-1}$ with an average concentration of $5100 \mathrm{mg} \cdot \mathrm{kg}^{-1}$. These values were higher than the results in the present study.

In 2015, after the CTN discussed the availability of an analytical method that would allow for the quantification of $\mathrm{Pb}$ content in paint products, the principal aim was not only to validate the methodology but also to begin improving the production processes for $\mathrm{Pb}$-free paints. However, according to the water-based paint results presented in Figure 3, no significant improvement or reduction of $\mathrm{Pb}$ content was observed. This situation is worrisome since, in 2019, the Pb threshold values came into force, and both manufacturers and marketing companies are aware that they are now active. Additionally, control processes have to be implemented to determine compliance with the regulations in question.

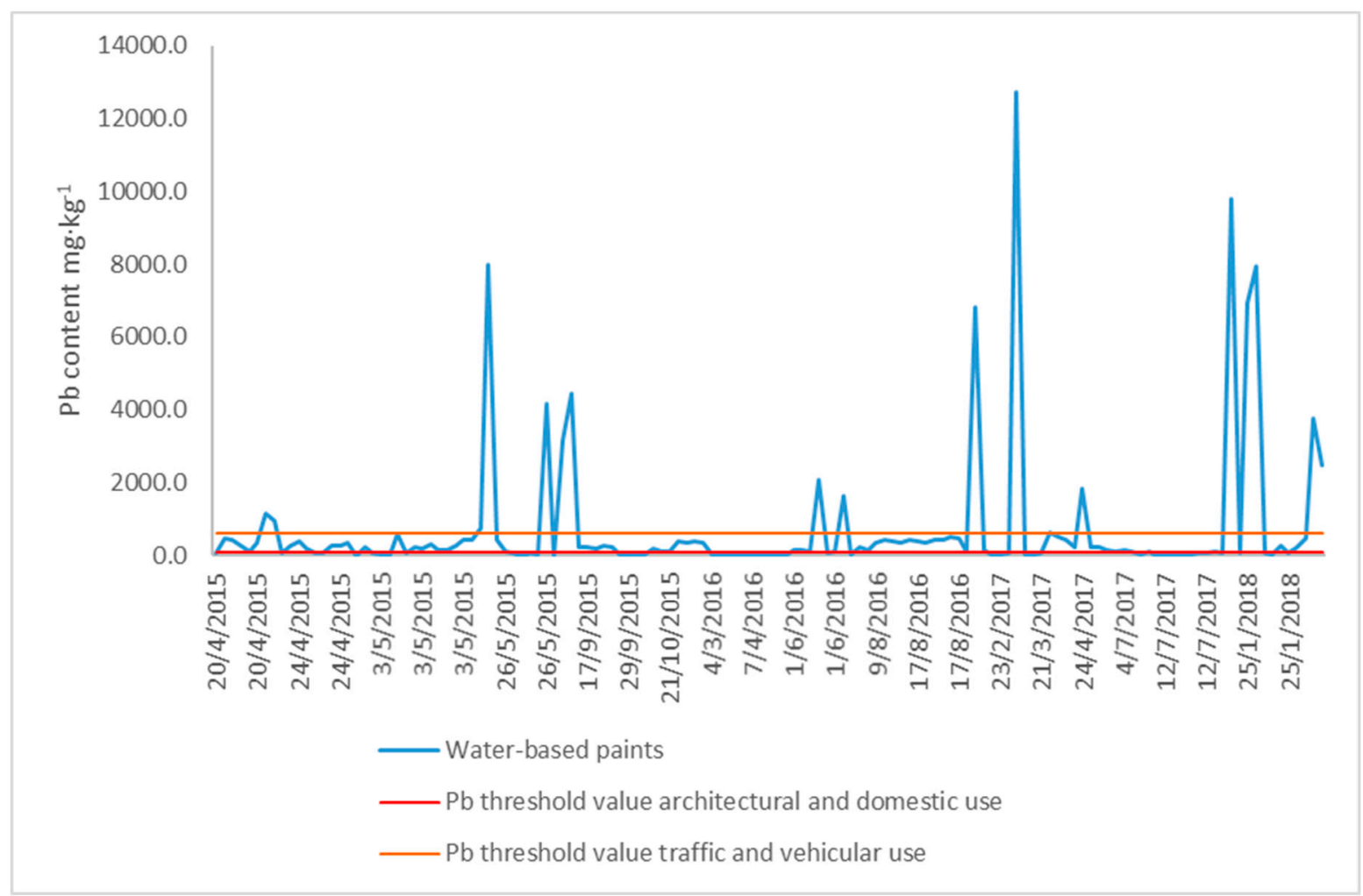

Figure 3. Lead content $\left(\mathrm{mg} \cdot \mathrm{kg}^{-1}\right)$ in water-based paint samples analyzed between April 2015 and February 2018.

\section{Conclusions}

The results of the current study show that the alkaline extraction method was satisfactory for determining $\mathrm{Pb}$ content in 10 types of paints and coatings: water-based paint, solvent-based paint, epoxy, alkyd enamels, synthetic enamels, lacquers, putties, pure pigments, preformed thermoplastics, and resins. The methodology was validated for quantifying $\mathrm{Pb}$ from concentrations up to $100 \mathrm{mg} \cdot \mathrm{kg}^{-1}$, which corresponds to the Ecuadorian regulations' [28,29] lowest threshold value, to the highest concentration analyzed of $21,044.5 \mathrm{mg} \cdot \mathrm{kg}^{-1}$.

The dry ashing and wet acid digestion techniques have some limitations, and it is difficult to have a complete control over them. It is also hard to guarantee the complete digestion or extraction of the $\mathrm{Pb}$ content. On the other hand, techniques such as inductively coupled plasma emission spectroscopy quantification and X-ray fluorescence are expensive. Thus, it is necessary to have reliable and relatively low-cost alternative methods available to control $\mathrm{Pb}$ content in paint products that are manufactured or marketed both nationwide and worldwide. 
The results of the water-based samples analyzed between April 2015 and February 2018 showed that, even when some threshold limit standards exist, there still are paint products with a high content of $\mathrm{Pb}$. This study was the first to quantify $\mathrm{Pb}$ content in different types of paint products with a relatively easy technique, in accordance with the Ecuadorian governmental authorities, responsible for controlling toxic metal content in different commercial products.

Author Contributions: Conceptualization, D.R.-E.; data curation, D.R.-E. and K.S.-F.; formal analysis, D.R.-E., K.S.-F., and P.Y.V.-T.; investigation, D.R.-E.; methodology, D.R.-E., K.S.-F., and P.Y.V.-T.; project administration, D.R.-E. and H.N.; resources, H.N.; validation, D.R.-E., K.S.-F., and P.Y.V.-T.; writing-original draft, D.R.-E.; and writing-review and editing, G.S.Y.-J.

Funding: This research received no external funding. The sample analysis service was paid for by the CNT and local manufacturers and marketers.

Acknowledgments: The authors would like to thank the Pontificia Universidad Católica del Ecuador for financial support. We also want to express our gratitude to the Ecuadorian Standardization Service (INEN) and to the CNT members for providing technical information and hiring us to perform the $\mathrm{Pb}$ content analysis on their paint products.

Conflicts of Interest: The authors declare no conflict of interest. The sponsors had no role in the design, execution, interpretation, or writing of the study.

\section{References}

1. Ericson, B.; Hariojati, N.; Susilorini, B.; Fisher, L.; Fuller, R.; Patrick, M.; Caravanos, J. Assessment of the prevalence of lead-based paint exposure risk in Jakarta, Indonesia. Sci. Total Environ. 2019, 657, 1382-1388. [CrossRef] [PubMed]

2. Gottesfeld, P. Toxic hypocrisy. New Sci. 2013, 218, 26-27. [CrossRef]

3. ASTDR. ToxFAQs ${ }^{\mathrm{TM}}$-Plomo (Lead). 2016. Available online: https://www.atsdr.cdc.gov/es/toxfaqs/es_tfacts13. html (accessed on 2 September 2019).

4. Berman, T.; Barnett-itzhaki, Z.; Reicher, S.; Ardi, R.; Shammai, Y.; Aruas, L.; Negev, M. Lead in spray paint and painted surfaces in playgrounds and public areas in Israel: Results of a pilot study. Sci. Total Environ. 2018, 637-638, 455-459. [CrossRef] [PubMed]

5. Gottesfeld, P.; Pokhrel, D.; Pokhrel, A.K. Lead in new paints in Nepal. Environ. Res. 2014, 132, 70-75. [CrossRef] [PubMed]

6. Hwang, Y.; Kate, C.; Lin, P. Globally temporal transitions of blood lead levels of preschool children across countries of different categories of Human Development Index. Sci. Total Environ. 2019, 659, 1395-1402. [CrossRef] [PubMed]

7. WHO. Lead Poisoning and Health. 2018. Available online: https://www.who.int/news-room/fact-sheets/ detail/lead-poisoning-and-health (accessed on 2 September 2019).

8. O'Connor, D.O.; Hou, D.; Ye, J.; Zhang, Y.; Sik, Y.; Song, Y.; Coulon, F.; Peng, T.; Tian, L. Lead-based paint remains a major public health concern: A critical review of global production, trade, use, exposure, health risk, and implications. Environ. Int. 2018, 121, 85-101. [CrossRef] [PubMed]

9. Clark, C.S.; Kumar, A.; Mohapatra, P.; Rajankar, P.; Nycz, Z.; Hambartsumyan, A.; Astanina, L.; Roda, S.; Lind, C.; Menrath, W.; et al. Examination of lead concentrations in new decorative enamel paints in four countries with different histories of activity in lead paint regulation. Environ. Res. 2014, 132, 233-243. [CrossRef] [PubMed]

10. UNEP/IPEN. Lead in Enamel Decorative Paints National Paint Testing Results: A Nine Country Study. United Nations Environ. Program. 2013. Available online: http://wedocs.unep.org/handle/20.500.11822/22872 (accessed on 2 September 2019).

11. ASTM. D3335-85a Standard Test Method for Low Concentrations of Lead, Cadmium, and Cobalt in Paint by Atomic Absorption Spectroscopy; ASTM International: West Conshohocken, PA, USA, 2014; pp. 1-4. [CrossRef]

12. EPA. Pb-Based Paint Laboratory Operations Guidelines: Analysis of Pb in Paint, Dust, and Soil. Tech. Programs Branch. 1993. Available online: https://www.epa.gov/lead/pb-based-paint-laboratory-operationsguidelines-analysis-pb-paint-dust-and-soil-revision-10-epa (accessed on 2 September 2019). 
13. Greifer, B.; Maienthal, E.J.; Rasberry, S.D. Development of NBS Standard Reference Material: NO. 1579 Powdered Lead-Based Paint. 1973. Available online: https://trove.nla.gov.au/work/21688327? selectedversion=NBD415897 (accessed on 2 September 2019).

14. Markow, P.G. Determining the Lead Content of Paint Chips: An Introduction to AAS. J. Chem. Educ. 1996, 73, 178-179. [CrossRef]

15. Truman State University. Determination of Lead in Paint Chip Samples Using Flame Atomic Experimental Procedure: Part A-Sample Preparation: CHEM. 2015. Available online: http://chemlab.truman.edu/files/ 2015/07/Pblab.pdf (accessed on 2 September 2019).

16. Clark, C.S.; Speranskaya, O.; Brosche, S.; Gonzalez, H.; Solis, D.; Kodeih, N.; Roda, S.; Lind, C. Total lead concentration in new decorative enamel paints in Lebanon, Paraguay, and Russia. Environ. Res. 2015, 138, 432-438. [CrossRef] [PubMed]

17. ASTM. E1613-12: Standard Test Method for Determination of Lead by Inductively Coupled Plasma Atomic Emission Spectrometry (ICP-AES), Flame Atomic Absorption Spectrometry (FAAS), or Graphite Furnace Atomic Absorption Spectrometry (GFAAS) Techniques; ASTM International: West Conshohocken, PA, USA, 2012; pp. 1-9. [CrossRef]

18. IOMC/WHO. Brief Guide to Analytical Methods for Measuring Lead in Paint, WHO Library Cataloguing-in-Publication Data. 2011. Available online: https://www.who.int/ipcs/assessment/public_ health/lead_paint.pdf (accessed on 2 September 2019).

19. Hobbs, A.L.; Almirall, J.R. Trace elemental analysis of automotive paints by laser ablation-inductively coupled plasma-mass spectrometry (LA-ICP-MS). Anal. Bioanal. Chem. 2003, 376, 1265-1271. [CrossRef] [PubMed]

20. Gondal, M.A.; Nasr, M.M.; Ahmed, M.M.; Yamani, Z.H.; Alsalhi, M.S. Detection of lead in paint samples synthesized locally using-laser-induced breakdown spectroscopy. J. Environ. Sci. Health Part A 2011, 46, $42-49$. [CrossRef] [PubMed]

21. Lau, O.W.; Li, K.L. The Determination of Lead and Cadmium in Paint by Atomic-absorption Spectrophotometry Utilising the Delves Micro-Sampling Technique. Analyst 1975, 100, 430-437. [CrossRef]

22. INEN. NTE INEN 2093:1998. Pinturas y productos afines. Determinación de plomo total método de espectrometría por absorción atómica. 1996. Available online: http://apps.normalizacion.gob.ec/descarga/ (accessed on 2 September 2019).

23. ISO. ISO 6503:1984. Paints and Varnishes-DETERMINATION of Total Lead-Flame Atomic Absorption Spectrometric Method. 1984. Available online: https://www.iso.org/standard/12880.html (accessed on 2 September 2019).

24. McBride, M.B.; Goodman, B.A.; Russell, J.D.; Fraser, A.R.; Frame, V.C.; Dickson, D.P.E. Characterization of iron in alkaline EDTA and NH4OH extracts of podzols. J. Soil Sci. 1983, 34, 825-840. [CrossRef]

25. Ntumba Malenga, E.; Mulaba-Bafubiandi, A.F.; Nheta, W. Alkaline leaching of nickel bearing ammonium jarosite precipitate using $\mathrm{KOH}, \mathrm{NaOH}$ and $\mathrm{NH}_{4} \mathrm{OH}$ in the presence of EDTA and $\mathrm{Na}_{2} \mathrm{~S}$. Hydrometallurgy 2015, 155, 69-78. [CrossRef]

26. Karczewska, A.; Milko, K. Effects of Chelating Agents on Copper, Lead and Zinc Solubility in Polluted Soils and Tailings Produced by Copper Industry. Ecol. Chem. Eng. A 2010, 17, 395-403.

27. Ding, Z.; Wang, Q.; Hu, X. Extraction of Heavy Metals from Water-Stable Soil Aggregates Using EDTA. Procedia Environ. Sci. 2013, 18, 679-685. [CrossRef]

28. INEN. NTE INEN 1544:2018. Pinturas Arquitectónicas. Pinturas en Emulsión base Agua (LATEX). Requisitos. 2018. Available online: http://apps.normalizacion.gob.ec/descarga/ (accessed on 2 September 2019).

29. INEN. NTE INEN 2284:2018. Pinturas. Lacas Catañizadas al ácido para Acabados sobre Madera. Requisitos. 2018. Available online: http://apps.normalizacion.gob.ec/descarga/ (accessed on 2 September 2019).

30. INEN. NTE INEN 2095:2017. Pinturas. Esmaltes Alquídicos Modificados para Vehículos. Requisitos. 2017. Available online: http://apps.normalizacion.gob.ec/descarga/ (accessed on 2 September 2019).

31. INEN. NTE INEN 1042:2009. Pinturas para señalamiento de tráfico. Requisitos. 2009. Available online: http://apps.normalizacion.gob.ec/descarga/ (accessed on 2 September 2019).

32. INEN. NTE INEN 2094:2013. Pinturas. Esmaltes alquídicos sintéticos para uso doméstico. Requisitos. 2013. Available online: http://apps.normalizacion.gob.ec/descarga/ (accessed on 2 September 2019).

33. INEN. NTE INEN 1043:2001. Pinturas. Imprimantes anticorrosivos con vehículo alquídico. Requisitos. 2001. Available online: http://apps.normalizacion.gob.ec/descarga/ (accessed on 2 September 2019). 
34. INEN. NTE INEN 1044:2001. Pinturas. Recubrimientos anticorrosivos para altas temperaturas. Requisitos. 2001. Available online: http://apps.normalizacion.gob.ec/descarga/ (accessed on 2 September 2019).

35. INEN. NTE INEN 2287:2001. Pinturas. Masillas nitrocelulósicas y de poliester. Requisitos. 2001. Available online: http://apps.normalizacion.gob.ec/descarga/ (accessed on 2 September 2019).

36. INEN. NTE INEN 1616:1987. Pinturas para señalamiento de tránsito en aeropuertos. Requisitos. 1987. Available online: http://apps.normalizacion.gob.ec/descarga/ (accessed on 2 September 2019).

37. INEN. NTE INEN 1045:1983. Pintura anticorrosiva esmalte alquídico brillante. Requisitos. 1983. Available online: http://apps.normalizacion.gob.ec/descarga/ (accessed on 2 September 2019).

38. INEN. NTE INEN 1046:2001. Pinturas. Imprimantes anticorrosivos con vehículo epóxico. Requisitos. 2001. Available online: http://apps.normalizacion.gob.ec/descarga/ (accessed on 2 September 2019).

39. INEN. NTE INEN 2280:2001. Pinturas. Lacas nitrocelulósicas para repintado de vehículos. Requisitos. 2001. Available online: http://apps.normalizacion.gob.ec/descarga/ (accessed on 2 September 2019).

40. INEN. NTE INEN 2281:2001. Pinturas. Lacas acrílicas para repintado de vehículos. Requisitos. 2001. Available online: http://apps.normalizacion.gob.ec/descarga/ (accessed on 2 September 2019).

41. INEN. NTE INEN 2282:2001. Pinturas. Sellador nitrucelulósico lijable para madera. Requisitos. 2001. Available online: http://apps.normalizacion.gob.ec/descarga/ (accessed on 2 September 2019).

42. INEN. NTE INEN 2283:2001. Pinturas. Lacas nitrocelulósicas para acabados sobre madera. Requisitos. 2001. Available online: http://apps.normalizacion.gob.ec/descarga/ (accessed on 2 September 2019).

43. INEN. NTE INEN 2285:2001. Pinturas. Barnices alquídicos de secamiento al aire. Requisitos. 2001. Available online: http://apps.normalizacion.gob.ec/descarga/ (accessed on 2 September 2019).

44. INEN. NTE INEN 2286:2001. Pinturas. Fondos nitrocelulósicos para repintado en la industria automotríz. Requisitos. 2001. Available online: http://apps.normalizacion.gob.ec/descarga/ (accessed on 2 September 2019).

(C) 2019 by the authors. Licensee MDPI, Basel, Switzerland. This article is an open access article distributed under the terms and conditions of the Creative Commons Attribution (CC BY) license (http://creativecommons.org/licenses/by/4.0/). 